\title{
Personal Laws and Religious Practice
}

\author{
Joby Bhasker"
}

Assistant Pofessor, Government Law College, Thrissur, Law College Road, Madona Nagar, Ayyanthole, Thrissur, Kerala 680003, India

\begin{tabular}{ll}
\hline DOI: $10.36348 /$ sijlcj.2019.v02i12.001 & | Received: 03.12.2019| Accepted: $10.12 .2019 \mid$ Published: 22.12 .2019 \\
*Corresponding author: Joby Bhaskar &
\end{tabular}

Abstract

The paper explores the historical panorama of the personal law system in India and scrutinizes the social and political factors that contributed towards the expansion and preservation of personal laws in India over the period of time.

Keywords: Indian legal system, Personal Law, Constitution.

Copyright @ 2019: This is an open-access article distributed under the terms of the Creative Commons Attribution license which permits unrestricted use, distribution, and reproduction in any medium for non-commercial use (NonCommercial, or CC-BY-NC) provided the original author and source are credited.

\section{INTRODUCTION}

The Indian legal system has to deal with demands of a multicultural society where each group follow their own personal law which governs their personal matters. The uniqueness of personal law lies in the fact that there validity and scope is not derived from legislative or judicial intervention. Muslim and Hindu laws owes their origin from their own sacred texts. Let it be during the Muslim rule or British dominion; religious practices and their legal sanctification were always kept serene by social economic and political vicissitudes. This 'unique' nature of personal law reaches deliberation in the constitutional era on the paradox of fundamental right to religion on one hand and uniform civil code on other rim. This article probes into the legislative imperviousness of personal laws from a constitutional, legislative and judicial perspective.

\section{The legislative interventions on personal law and religious freedom}

The rich and myriad history of India portrays that, it had a time when religion regulated nearly every aspect of social and personal life [1]. As time passed and the fields of applicability have since been carved away, it still cuddle many aspects of life such as marriage, divorce, adoption, succession, inheritance, minority, guardianship, etc. And it's interesting to notice that these laws are beyond legislative compass because of their divine origin. Many areas of Hindu and Muslim laws have remained unaffected by centuries of political vicissitudes and socio- economic upheavals.

${ }^{1}$ Dhirendra K. Srivastava, Religious Freedom in India 212 (Deep \& Deep Publication, New Delhi, 1983)
During the six hundred years of Muslim rule, the legislature did not interfere with Hindu Law [2]. Even after two hundred years of European domination, especially of British, the fundamental areas of Muslim and Hindupersonal laws enjoyed complete immunity from legislation [3]. The British implemented the policy of non-interference in the personal laws of the local population [4].

The British regime followed a concept of 'interpersonal conflict of laws' [5]. They assumed that any effort to enact personal laws would surely lead to 'injury to religious susceptibilities' because of the inviolable connection between religion and personal laws [6]. Even though after independence Indian enacted many legislations related to personal laws, they also follow the same policy as that of British. In modern India these personal laws operate in a narrow field only. Although the legislature interfered with various aspects of the classic Hindu personal law, other personal law

\footnotetext{
${ }^{2}$ R. C. Majumdar and S. Chaudhari, The Mughal Empire 25- 31 (BharatiyaVidyaBhavan, Bombay, 1974)

${ }^{3}$ K.M. Panikar, A survey of Indian History 109-169 (Asia Publishing House, London, $4^{\text {th }}$ ed., 1964)

${ }^{4}$ Christa Rautenbach, "Phenomenon of personal laws in India: some lessons for South Africa", The Comparative and International Law Journal of Southern Africa, Vol. 39, No. 2(JULY 2006), pp. 241-264, p.242.

${ }^{5}$ David Pearl,A textbook on Muslim law (Croom Helm Publishers , London (2ed 1987) p. 9

${ }^{6}$ David Pearl,A textbook on Muslim law (Croom Helm Publishers , London (2ed 1987) p. 9
} 
systems such as the Muslim and Jewish, remain to a large extent unaffected [7].

British rule from its inception followed a policy of non-interference in religious matters of Hindus and Muslims. Even when the Mayor's court were established at Calcutta, Bombay and Madras in 1726 , cases of religious nature between natives was completely ousted from its jurisdiction by the Governor and Council of Company [8]. The Charter Act of 1753 expressly exempted the Indians from the Mayor's Courts jurisdiction and directed that such suits and disputes should be determined by the Indian themselves, unless both parties submitted themselves to the jurisdiction of the court [9].

Legislative intervention of British period helped a lot in improving the social status and legal position of Hindu women. In other words, though there were deliberate legislative interventions in religious practice it was sought for socio legal advancement.

Interpretations and elucidations by religious scholars on Vedas and Vedic texts with their bias and prejudices on women deteriorated not only the personal liberties of women, but even depreciated them in all facets of social life. Consequently they had a substandard stance in the eyes of law. Some deliberate legislative reforms was the need of the time to improve the position of women in social and political life. Responding to this social circumstances and the demand for change from social reformists the British Government came with piece meal legislations to enhance the social life of women. In 1829 the practice of 'Sati' was abolished.10 Muslim and Hindu laws of property in relating to apostates were abrogated in 1850 by the Caste Removal Disabilities Act, 1850 [11].

Next revolutionary legislative intervention was by legalizing the remarriage of Hindu widows. By the Hindu Widow Remarriage Act of 1856, Hindu widows were allowed to remarry. Another facilitating enactment was the Hindu Women's Rights to Property Act, 1937. By this enactment Hindu women got some property rights which they were denied previously. This was a radical challenge to the Mitakshara school which denied

${ }^{7}$ Christa Rautenbach, p. 244.

${ }^{8}$ M.P.Jain, Indian Legal History 60-61 (|N.M. Tripathi, Bombay, $2^{\text {nd }}$ ed., 1966)

9 U.C. Sarkar, Epochs in Hindu Legal History (Visheshvaranand Vedic Research Institute, Hoshiarpur, 1958),p.23

10 The difficulties faced by the British administrator in reaching and implementing this decision are described in K. Ballhatchet, Social Policy and Social Change in Western India, p.p. 275-91 \& PP. 298-305.

11 D.K. Srivastava, Religious Freedom in India, p. 235 (New Delhi 1982, p. 234. the right to property and succession to women. The rules and practices of partition, coparcenaries and alienation was traumatized. The age old Hindu practices inheritance and adoption was thoroughly distorted [12].

After ten years British came with another significant legislation.The Hindu Married Women's Rights to Separate Residence and Maintenance Act, of 1946 facilitated a married Hindu woman, even during the continuance of marriage to demand separate maintenance and residence from her husband under certain circumstances mentioned in the Act [13]. The Hindu Adoption and Maintenance Act, 1956 (Act 78 of 1956) has repealed this law now [14].

Another set of statutes were enacted to eradicate some highly objectionable practices which had come to have legal and customary sanctions amongst the Hindus. The first step in this regard was the abolition of the inhuman practices of 'Sati'. To discourage the practice of child marriage, the Child Marriage Restraint Act was passed in 1929.

There are few other legislations passed by the British administration which effected remarkable changes in the old Hindu joint family law and the laws of inheritance. These Acts made considerable inroads on the principles of succession and inheritance previously regarded as binding by the old Hindu law [15]. The Hindu Inheritance (Removal of Disabilities) Act, 1928, laid down that no person, except one who had been lunatic or idiot from birth, would be excluded from inheritance by reason only of his disease, deformity, physical or mental defect. The Act applies only of Mitakshara school and not to Dayabhaga school. The Hindu Law of Inheritance (Amendment) Act of 1929 altered the order of the intestate succession under the Mitakshara law with a view to prefer certain near cognates to agnates. Thus son's daughter, daughter's daughter, sister and sister's son were declared to be entitled to succeed next after the paternal grand-father. This was the result of realization that the Sastric law needed to be altered in order to bring the rules of inheritance in congruence with the dictates of natural love and affection. The Hindu Gains of Learning Act, 1930, declared that all acquisitions of property made substantially by means of learning shall be 'the exclusive and separate property of the acquire' [16]. Before the passing of the Act, under the

12 Mayne's Hindu Law and Usage, p. 59 (12th Ed. 1986) Rev.by A Kuppuswami.

13 The Hindu Married Women's Rights to Separate Residence and Maintenance Act, 1946, Section 2.

14 Mayne's Hindu Law and Usage, p. 57 (12th Ed. 1986) Rev.by A Kuppuswami..

15 U.C. Sarkar, Epoch in Hindu Legal History, p. 372 (Hoshiarpur: Visheshvaranand Vedic Research Institute 1958).

16 Sections 2(b) and 3 of the Act 
circumstances, such acquisitions could be regarded as ‘joint and liable to partition' [17].

The enactment of two other Acts [18], dealt a severe blow to Hindu religion. Since time immemorial the institution of caste has been used to structure and perpetuate Hindu society. The Hindu Wills Act of 1870 for the first time conferred a power of testamentary disposition of Hindus. Wills were previously unknown to Hindu law. In 1941 the British-Indian Government appointed a committee under the chairmanship of Sir B.N. Rau to study the question. It was not without a tremendous amount of courage and under heavy criticism of not only 'traditionalists' and religious groups, but some of the well-meaning and intelligent lawyers also, that the Rau Committee suggested the enactment of Hindu Code [19]. It was not however, so easy to touch the sacred religious law of the Hindu, unwilling to accept the codified enactments and unprepared to give up the 'divine law' propounded by their great sages. Even President Rajendra Prasad was opposed to the enactment of the Hindu Code Bill [20]. The Central Government was, however, determined. The result was that the Hindu Code Bill came to be divided into different parts and passed one by one in the form of four different Act, 1956; Hindu Minority and Guardianship Act 1956, and Hindu Succession Act, 1956; Hindu Minority and Guardianship Act, 1956; and Hindu Adoption and Maintenance Act, 1956. Despite strong protests of the orthodox and conservatives [21] these enactments struck down the old out-moded law and modified it and changed it according to the changed spirit of the time [22]. Nevertheless, the present system has its roots in the past and derives its mains principles from the age-old 'dharma law' [23].

The effect of these four legislations has been that they have introduced considerable departure from the traditional Hindu law. For example, in the area of marriage, monogamy and divorce have been introduced. Both of these were unknown to the old Hindu law. Such western concepts as judicial separation, cruelty,

17 U.C. Sarkar, Epoch in Hindu Legal History, pp. 374 (Hoshiarpur: Visheshvaranand Vedic Research Institute 1958).

18 Act III of 1872 and Arya Marriage Validation Act of 1937.

19 R.P. Anand, 'Hindu Law in Historical Perspective' p. 33, (1966) II SCJ.

20 Setalvad, cited by M. P. Jain, Supra n. 4, p. 490

21 Nanda, 'Marriage and Divorce in India: Conflicting Law' 55 North Western University Law Review, p. 632 (1960) and literature quoted therein.

22 R.P. Anand, 'Hindu Law in Historical Perspective' p. 33, (1966) II SCJ.

23 Generally Derrett, 'The Codification of Personal Law in India : Hindu Law', 6 Indian year Book of International Affairs, p.p. 189-211 (1957). desertion, nullity of marriage have been introduced into the marriage law with the result that courts freely cite English cases to expound the meaning of these concepts and law has become Anglo-Hindu Law [24].

These Acts govern a large section of Indian people as they apply to Jains, Sikhs, Budhists and Hindus of all denominations and castes. A distinction, however, has been maintained between Mitakshara and Dayabhaga schools by the Hindu Succession Act. The most complicated area of the Joint Hindu family, has been left untouched and for the present there is no move to codify this branch of law.

The Hindu Adoption and Maintenance Act, has also brought about some fundamental changes in the concept of adoption under Hindu Law. Previously, the concept of adoption was a purely religious one, but the present Act seeks to make it a non-religious affairs, to a large extent. Even the laws, relating to minority and guardianship, have been greatly modified by the Minority and Guardianship Act.

During the six decades between 1827 and 1887, there were several Acts regulating the laws to be applied by local civil courts in numerous provinces, which recognized the supremacy of custom and usage over the rules of personal laws [25]. Due to this statutory recognition of custom and usage, certain sections of Muslims of India [26], followed customary laws in matters relating to succession or inheritance which were contrary to the Islamic Jurisprudence. Religious leaders of Muslims all over the country felt that the situation called for express legislation superseding customs, conflicting with Islamic law [27].

The Mopilla Muslims of South India were the first to make efforts for securing compulsory application of Islamic law. They succeeded in 1918 when the Mapilla Succession Act was passed in Madras. The Act provided that, notwithstanding any custom to the contrary, intestate property of a deceased Mapilla would devolve in the order of inheritance under "Muhammadan Law" [28]. Ten years later the Mapilla Wills Act, 1928 was enacted to deal with the cases of testamentary succession among the Mapilla of South India.

24 M.P. Jain, Outlines of Indian Legal History, p. 490 (4th ed. 1981).

25 The Madras Civil Court Act, 1873, S-16and the corresponding provisions enacted for other provinces.

26 For example Maplla Muslims of South India and Cutchi Memons were governed by their old customary law of succession and inheritance.

27 Tahir Mahmood, 'Legislation for the Muslims in British India' in 'An Indian Civil code and Islamic Law’ p. 53 (1976, Tripathi; Bom.).

28 Section 3 of the Act. 
Two years later, the Cutchi Memons also succeeded in their efforts by getting Cutchi Memons Act, 1920, enacted. This Act, however, made the application of "Muhammadan Law" of succession and inheritance optional. Unsatisfied with the provisions the Memons continued their efforts; and finally the Cutchi Memons Act, 1938 was enacted. The Act provided that all Cutchi Memons will be governed by "Muhammadan Law". The Act is now applicable in Tamil Nadu and Andhra Pradesh. Mysore and Kerala have, also, similar Acts enacted by local legislatures [29].

The laws applicable to Mapillas and Cutchi Memons were confined to inheritance and succession. But in some other parts of the country, customs contrary to Islamic law were being followed by Muslims in relation to other matters also. Against such practices a movement began in the early thirties of the present century in the frontier province, leading to the enactment of an Act in 1935, by the provincial assembly. The Act provided that in all cases of marriage, divorce, succession and other family affairs Muslims would be governed compulsorily by "Muhammadan Law".

Inspired by this legislation, the Punjabi Muslims endeavoured to secure a similar law having a country-wide application. They had been counseled in this regard by Maulana Ashraf Ali Thanavi, Maulvi Abdul Karim Gumathalvi and other luminaries of Jamiat-al-Ulema Hind. In 1935, one Hafiz Abdullah Layalpuri drafted a Bill for the purpose. When moved in the central legislature Mohammad Ali Jinnah proposed some significant amendments in its provisions. Eventually a law was enacted in 1937 under the title: The Muslim Personal Law (Shariat) Application Act.

The Shariat Act, 1937, came into operation on 7th October, 1937, and is applicable throughout India. It applies to every Muslim of whatever sect or school. One provision of the Act lists those matters which among Indian Muslims, shall invariably be governed by the Muslim personal law [30]. There are; (i) marriage, (ii) dissolution of marriage in any form, (iii) guardianship, (iv) dower, (v) maintenance, (vi) gifts, (vii) trusts, (viii) waqf and (ix) intestate succession (excepting that concerning agricultural lands) [31].

Another provision mentions those matters in regard to which the application of Muslim personal law

\footnotetext{
29 The Mysore Cutchi Memons Act, 1943; Cochin Cutchi Memons Act 1106F; Tranvancore Cutchi Memons Act, 1117F.

30 Sec-2 of the Act.

31 Succession of agricultural lands, being a provincial subject under the Government of India Act, 1935, fell outside the jurisdiction of the central legislature which passed this Act.
}

would depend on the option of an individual; once exercised the option being binding also on the maker's minor children and their descendants. These matter are: (i) adoption, (ii) wills and (iii) legacies [32].

Indian citizens had some provisions which would normally affect certain areas of Muslim personal law. To exempt Muslim legal institutions from the application of such laws, protective provisions were specifically included in them. For example - Sections 2 and 129 of the Transfer of Property Act, 1882, section 1 of the Indian Trusts Act and relevant provisions of the Indian Succession Act, 1925.

The Oudh Laws Act of 1876 was the first legislative step in British India, which affected a substantive provision of Muslim personal law. That was an Act of regional extension now applicable in ten districts of Uttar Pradesh which constituted the erstwhile Oudh State. Sec. 5 of the Act empowers the courts to make a reduction in the amount of dower, payable under a marriage contract, in accordance with the husband's means and wife's status, at the time of payment. In 1920 an identical power was conferred on the courts in the State of Jammu and Kashmir under the J\&K State Muslim Dower Act, 1920.

The Dissolution of Muslim Marriage Act, 1939, happens to be the most important legislation in British India, having regard to the source and method of legislation. This Act empowers the court to dissolve a marriage at the wife's request on the grounds enumerated under Section 2. The Act also provides that renunciation of Islam by a Muslim wife would not 'ipso facto' dissolve her marriage, except when a women converted to Islam ceases to be Muslims by reverting to her former religion [33].

Another significant legislation in British India on Muslim personal law is a Mussalman Wakf Validating Act, 1913. This Act was passed to undo the Privy Council's judgment in Abul Fata v. Russomoy Dhur Chowdhury [34], which invalidated the family waqf (or waqf-alal-auld) an institution recognized since long under the traditionally established Islamic law of waqfs. The Privy Council held that such waqf were created merely to give a 'colour of piety' to arrangement made for 'aggrandizement of families'. This decision led to forceful opposition by different sections of Muslims. Allama Shibi Nomani and Syed Amir Ali demanded statutory restoration of the traditional law. In this historical background the Act of 1913 was enacted; and it was given retrospective effect by a supplementary Act enforced in 1930.

$\begin{array}{ll}32 & \text { Section } 3 \text { of the Act. } \\ 33 & \text { Section } 4 \text { of the Act. } \\ 34 & \text { (1894) } 22 \text { I.A. } 76 .\end{array}$


During the framing of the Constitution an effort was made by the Muslim members of the Constituent Assembly to crave out a guarantee in the provision dealing with the fundamental right to religious freedom (Article 25) to the effect the personal laws of any community would not be altered [35]. However, the final form of the words incorporated in Article 25(1) and (2) did not create any exception in favour of any community. Constitution of India, nevertheless, recognizes, 'the personal laws' by vesting the legislative power in the Parliament and the State legislation on "all matters in respect of which the parties in judicial proceedings were, immediately before the commencement of this Constitution, subject to their personal laws, including, inter alia matters like 'marriage and divorce' infants and minors' adoption; will, intestacy and succession; joint family and partition' [ 36 ]. But the most problematic and controversial provision of the Indian Constitution with regard to personal laws, is Article 44 which requires the state to 'endeavour to secure for the citizens a uniform civil code throughout the territory of India'. Inspite of being only a 'directive and thus legally un-enforceable, this Article has provoked serious debates both on the judicial platform and elsewhere.

Keeping the constitutional provisions aside, the legislative response to 'personal laws', particularly the Muslim personal law in the Independent-India, has not undergone any significant change from the BritishIndia. The only significant legislation, after Independence, in the era of substantive Muslim personal law is the Muslim Women (Protection of Rights of Divorce) Act, 1986. This Act was enacted to do away with the controversy created by the Supreme Court's judgment in Shah Bano case [37], relating to maintenance of divorced Muslim women. This judgment was contrary to the provisions of Islamic Shariat. As a reaction to the judgement the entire Muslim community, except few so-called progressive Muslims, organized protest for weeks throughout the country for the protection of Shariat [38]. The All India Muslim Personal Law Board, drew the attention of the then Government towards the flaws in the judgment and demanded for the restoration of the Islamic law regarding maintenance of divorced Muslim women. This and other political developments, led to the introduction of Muslim Women's Bill in the Lok Sabha

35 S. Khalid Rashid, Muslim Law, pp.37-38 (3rd ed.
1996).
Item 5, List III, Schedule VII of the Constitution
of India.
Mohd. Ahmad Khan v. Shah Bano, AIR 1985 SC
945.
Dr. Saleem Akhtar, Shah Bano Judgment in Islamic Perspective, p. 341 (1st ed., 1994 Kitab Bhavan New Delhi.) during the last week of February, 1986 [39]. The Bill ultimately took the shape of the present Act.

Like British India, in Independent India also, laws regulating the procedural aspect of the institutions under Muslim personal law have been enacted by both Union and State legislatures. Most of these enactments are concerned with the 'Waqfs'. These are procedural in nature and do not affect the substantive provisions of Muslim law. Some such enactments are - The Waqf Act, 1954; The Durgha Khawaja Sahib Act, 1955, The Durgah Khawaja Sahib (Emergency Provision) Act, 1950; The Durgha Khawaja Sahib (Amendment) Act, 1964; The Public Waqfs (Extension of Limitation) Amendment Act, 1959; The U.P. Muslim Waqf Act, 1960; The U.P. Muslim Waqf (Amendment) Act, 1964; The Waqf (Amendment) Act,

\section{CONCLUSION}

In India, personal laws are the distinct products of multi-cultural system evolved through generations. Even though the relation between personal law and religious is considerable remote, because of sentimental reverence of people to the 'living law' of tradition, the task of attaining social justice in this sphere is resisted by some orthodox sections of the society directly or indirectly. However, the majority of the population has favourably responded to the introduction of social reforms in their personal law. But the experience of the law maker in the direction of Uniform Civil Code is that effecting changes even in an incremental manner is very difficult.

The analysis made above shows that there is the snag of non enforceability which hinders the Directive Principles of State Policy in becoming a powerful instrument of social engineering. The judicial process has been influenced to some extent in recent times. Judiciary has demonstrated in several cases that reading in Directive Principles into the elastic veins of Fundamental Rights is the profitable approach in translating the values goals in Part IV interstitially. However, the judicial path of attaining social justice in personal laws by application of the fundamental rights under Art. 14,15, 19, 21 and 25(2) (b) of the Constitution is strewn with self-created pitfalls. The unnecessary controversy on the question whether personal law is law for the purpose of Part III diluted the efficacy of judge made reform. However, recent pronouncements of the court (for example, pertaining to the constitutionality of Sec. 9 of Hindu Marriage Act) receive confidence in this regard. The need of judge made reform on the basis of Fundamental Rights is very much felt to-day in the backdrop of legislative inertia

39 Dr. Saleem Akhtar, Shah Bano Judgment in Islamic Perspective, p. 341 (1st ed., 1994 Kitab Bhavan New Delhi.). 
and agonizing injustice, exploitation and discrimination in some of the uncodified personal law.

There is no need for amending any provision of Part III relating to religious freedom to protect reforms in personal laws because the relation between personal law and religion is remote and also because no impediment on that ground is experienced by the judiciary or the legislature [40]. Further Art. 25(2) (b) is quite elastic.

It is obvious from the discussions so far that inspite of the best efforts of the Muslim members, the majority of the members of the Constituent Assembly, was unwilling to provide a constitutional protection to the 'personal laws of different communities for all time to come'. Instead they introduced article 44 which envisages a 'uniform civil code'. The Constitution, however, adopts the policy of continuity and changes under article 372 as far as personal laws are concerned.

As regards the conformity of personal laws with part III of the Constitution, the judicial attitude shows that this part does not touch upon the personal laws. The right to freedom of religion guaranteed under article 25 of the Constitution has been so interpreted by the courts that it provides little protection to personal laws. But so far as the question of recognition of personal laws is concerned, the Constitution does acknowledge the existence of such laws under Entry 5, List III of Seventh Schedule, together with article 372. The directive of uniformity under article 44 itself is recognition of the exiting variety of personal laws.

40 Tulzapurkar, J. is of the opinion that there is the need for constitutional amendment permitting reforms in personal law notwithstanding the guarantee of freedom of religion. It is submitted, Art. 25(2) (b) is quite elastic to allow such reforms even if it is considered that personal law is part of the religion. But it is generally accepted that personal law is remotely connected with religion. 